LINGUA, Vol. 15, No. 2, September 2018

p ISSN: 1979 9411; e ISSN: 2442 238X

Http://lingua.pusatbahasa.or.id; Email:presslingua@gmail.com

Center of Language and Culture Studies, Surakarta, Indonesia

Rosana, Nana; Mahyuni \& Burhanuddin. 2018. Estetika Resepsi Bahasa Sasak para Pembayun

dalam Upacara Adat Sorong Serah Masyarakat Sasak di pulau Lombok.

Lingua (2018), 15(2):187 206. DOI:10.30957/lingua.v15i2.526.

\title{
ESTETIKA RESEPSI BAHASA SASAK PARA PEMBAYUN \\ DALAM UPACARA ADAT SORONG SERAH MASYARAKAT SASAK DI PULAU LOMBOK
}

\author{
Nana Rosana ${ }^{1}$, Mahyuni ${ }^{2} \&$ Burhanuddin $^{3}$ \\ Magister Pendidikan Bahasa Indonesia Universita Mataram \\ Jl. Majapahit No. 62, Gomong, Selaparang, Dasan Agung Baru, Selaparang, \\ Kota Mataram, Nusa Tenggara Barat 83115 \\ Email: ${ }^{1}$ nanarosana1971@gmail.com, ${ }^{2}$ yonmahy@yahoo.com ${ }^{3}$ burhanuddinali@gmail.com
}

\begin{abstract}
The research was inspired by the beauty of the language used by the speaker called pembayun in the traditional sorong serah ceremony, the bridal application of Sasak people in Lombok. The tradition does happen however, young generations would have neglected the meaning denoted in the languages of the ceremony that contains high values of culture, wisdom and relegiousity. This study used content analysis and ethnography. Data were collected using observation, interview, documentation and records. Informants that were the native speakers of Sasak and Sumbawa and have the authority on the traditional ceremony were selected. The results results show: (1) aesthetically, the form of language used in the receptionn is the highest form in the Sasak language, which not all Sasak people are able to understand and use; (2) the aesthetic function of the reception of the swinging language in the sorong serah event is a means to convey the message, religion, custom and morals; and (3) the aesthetic value contained in the pembayun language refer very high moral values and needs to be known by the public at large.
\end{abstract}

Keywords: bridal application, sorong serah, serve and accept, aesthetic values.

DOI:10.30957/lingua.v15i2.526.

\section{PENDAHULUAN}

Penelitian ini merupakan kajian tentang ekspresi verbal dalam budaya perkawinan adat masyarakat Sasak di Pulau Lombok dan perkawinan adat masyarakat Samawa di Pulau Sumbawa. Kajian difokuskan pada ekspresi verbal saat pinangan menggunakan analisis semiotik. Aspek kajian adalah ekspresi verbal dalam komunikasi, simbol, serta nilai-nilai dan fungsi yang terkandung pada perkawinan kedua suku untuk diperbandingkan.

Perkawinan adat Suku Sasak memiliki tata cara unik dikenal dengan merariq dilanjutkan proses sorong serah aji krama sebagai pembanding bagi perkawinan adat Suku Samawa yang memiliki istilah bajajak, bakatoan, basaputis, nyorong, dan basai. 
LINGUA, Vol. 15, No. 2, September 2018

p ISSN: 1979 9411; e ISSN: 2442 238X

Http://lingua.pusatbahasa.or.id; Email:presslingua@gmail.com

Center of Language and Culture Studies, Surakarta, Indonesia

Rosana, Nana; Mahyuni \& Burhanuddin. 2018. Estetika Resepsi Bahasa Sasak para Pembayun

dalam Upacara Adat Sorong Serah Masyarakat Sasak di pulau Lombok.

Lingua (2018), 15(2):187 206. DOI:10.30957/lingua.v15i2.526.

Kedua suku dalam pekawinan adat masing-masing tentu memiliki unsur semiotik yang menjadi pusat kajian, seperti tipe atau pola, tata cara atau proses, tanda (ikon, indeks, dan simbol), nilai-nilai dan fungsi yang terkandung dalam perkawinan adat kedua suku. Pada perkawinan adat kedua suku, yang masing-masing mempunyai tata cara serta menggunakan perangkat berbeda merupakan fokus kajian untuk dianalisis secara cermat.

Salah satu tradisi yang melekat dengan upacara perkawinan dalam budaya masyarakat Sasak adalah acara sorong serah pada upacara perkawinan. Dalam wacana Sorong Serah terdapat ajaran moral, ketuhanan, hukum, sikap, pandangan hidup dan perbuatan toleransi antaranggota komunitas. Gerakan dan tutur kata, serta berbagai peralatan yang digunakan dalam acara Sorong Serah menjadi simbol atau lambang dari berbagai hal. Perlakuan dan bentuk benda yang digunakan adalah manifestasi dari keinginan masyarakat. Setiap gerakan, tutur kata dan alat yang digunakan mengandung nilai filosofis masing-masing.

Estetika sebagai wujud keindahan dalam karya sastra terdapat juga dalam wacana sorong serah. Estetika resepsi atau estetika tanggapan adalah esetetika (ilmu keindahan) yang didasarkan pada tanggapan-tanggapan atau resepsi-resepsi pembaca terhadap karya sastra (Pradopo, 2007:206). Sebagai salah satu usaha untuk tetap menjaga kelestarian budaya masyarakat Sasak, dilakukan penelitian yang berjudul Estetika Resepsi Bahasa Sasak Para Pembayaun dalam Upacara Adat Sorong Serah Masyarakat Sasak di Pulau Lombok. Adapun rumusan masalah penelitian ini ialah:

1. Bagaimanakah bentuk bahasa Sasak yang digunakan oleh para Pembayun dalam menyampaikan pesan pada upacara adat sorong serah masyarakat Sasak di pulau Lombok?

2. Bagaimanakah estetika resepsi masyarakat Sasak terhadap bahasa para pembayun dalam upacara adat sorong serah masyarakat Sasak di pulau Lombok?

\section{KAJIAN TEORI}

\subsection{Ekspresi Verbal}

Simbol atau pesan verbal adalah semua jenis simbol yang menggunakan satu kata atau lebih. Bahasa dapat juga dianggap sebagai sistem kode verbal. Bahasa dapat didefinisikan sebagai seperangkat simbol, dengan aturan untuk mengkombinasikan simbol-simbol tersebut, yang digunakan dan dipahami suatu komunitas. Komunikasi verbal adalah komunikasi yang menggunakan kata-kata, entah lisan maupun tulisan. Komunikasi ini paling banyak dipakai dalam hubungan antar manusia. Melalui katakata, mereka mengungkapkan perasaan, emosi, pemikiran, gagasan, atau maksud mereka, menyampaikan fakta, data, dan informasi serta menjelaskannya, saling bertukar perasaan dan pemikiran, saling berdebat, dan bertengkar. Dalam komunikasi verbal itu bahasa memegang peranan penting.

Pada dasarnya bahasa adalah suatu sistem lambang yang memungkinkan orang berbagi makna. Dalam komunikasi verbal, lambang bahasa yang dipergunakan adalah bahasa verbal entah lisan, tertulis pada kertas, ataupun elektronik. Bahasa suatu bangsa atau suku berasal dari interaksi dan hubungan antara warganya satu sama lain. 
Sekurang-kurangnya ada tiga fungsi yang erat hubungannya dalam menciptakan komunikasi yang efektif. Ketiga fungsi itu adalah untuk mempelajari tentang dunia sekeliling kita, membina hubungan yang baik di antara sesama manusia dan menciptaakan ikatan-ikatan dalam kehidupan manusia.

Kata merupakan unit lambang terkecil dalam bahasa. Kata adalah lambang yang mewakili sesuatu hal, entah orang, barang, kejadian, atau keadaan. Jadi, kata itu bukan orang, barang, kejadian, atau keadaan sendiri. Makna kata tidak ada pada pikiran orang. Tidak ada hubungan langsung antara kata dan hal yang berhubungan langsung hanyalah kata dan pikiran orang.

\subsection{Simbol Adat}

Perkawinan adat Suku Sasak yang unik yaitu merariq dilanjutkan proses sorong serah aji krama, menjadi pembanding bagi perkawinan adat Suku Samawa yang memiliki istilah bajajak, bakatoan, basaputis, nyorong, dan basai. Kedua suku dalam pekawinan adat masing-masing tentu memiliki unsur semiotik yang menjadi pusat kajian, seperti tipe atau pola, tata cara atau proses, tanda (ikon, indeks, dan simbol), nilai-nilai dan fungsi yang terkandung dalam perkawinan adat kedua suku.

Simbol dalam perkawinan adat adalah tanda yang petandanya tidak menunjukkan adanya hubungan alamiah, hubungan arbetrer berdasarkan konvensi seperti kata ibu (petanda) menandai orang yang melahirkan. Terkait dengan indeks dalam perkawinan adat Suku Sasak dan Suku Samawa yaitu makna dari bunyi-bunyian dan makana gerakan yang digunakan dalam upacara adat. Nilai-nilai yang dikaji dalam perkawinan adat Suku Sasak dan Suku Samawa berupa pesan moral dan religi yang terkandung di dalamnya sebagai acuan untuk menyatukan persepsi. Setiap budaya akan menyimpan nilai-nilai yang menjadikannya unik dan berbeda dengan kebudayaan lainnya. Nilai-nilai itu terkandung dalam perkawinan adat kedua suku, baik nilai moral, sosial, dan nilai agama.

\subsection{Perkawinan Suku Sasak}

Suku Sasak adalah salah satu suku bangsa yang secara mayoritas mendiami atau menjadi penduduk di Pulau Lombok Nusa Tenggara Barat. Suku yang mendiami Pulau Lombok ini memiliki adat perkawinan yang cukup unik dibandingkan dengan suku lainnya. Salah satu keunikan tersebut yaitu budaya merariq.

Budaya merariq dalam Suku Sasak merupakan salah satu keunikan tersendiri, karena terkenal dengan kawin lari. Hal ini terjadi sejak Suku Sasak ada atau lahir, dan sampai kini masih terus dipertahankan. Dikatakan kawin lari karena proses perkawinannya sendiri tidak melalui acara melamar atau meminang terlebih dahulu. Apabila pasangan yang akan melangsungkan perkawinan telah sepakat, maka mereka berjanji kapan akan menjalankan perkawinan. Biasanya akan dilakukan malam hari, karena tidak boleh diketahui oleh orang lain, sehingga sering disebut 1) melaiqang atao berarian, yang artinya membawa calon pengantin putri ke tempat calon pengantin laki.

Setelah proses melarikan calon pengantin putri, dilanjutkan dengan ritual khusus pada rumah calon suami. Oleh karena mayoritas Suku Sasak menganut agama Islam, 
maka setelah tiga hari akan dilakukan proses 2) sejati, yaitu calon pengantin laki-laki melaporkan diri kepada petugas pemerintah bahwa telah membawa perempuan sebagai calon istrinya, dan demikian juga dilakukan oleh pihak keluarga perempuan. Proses selanjutnya 3) nyelabar, pemberitahuan oleh keluarga laki-laki kepada keluarga perempuan bahwa anaknya benar-benar kawin. Selanjutnya, dilakukan proses 4) nuntut wali, yaitu pencarian wali kepada pihak keluarga perempuan dan hal ini dilakukan oleh petugas dari pemerintah. Sebagai proses selanjutnya adalah 5) ijab kabul atau akad nikah untuk mengikat janji antara pengantin laki-laki dan perempuan melalui wali pengantin perempuan.

Setelah proses ijab kabul, maka resmilah pasangan menjadi pengantin dan membina bahtera rumah tangga. Selanjutnya, untuk menjalankan tradisi tentu akan diadakan acara hajatan atau dalam istilah Suku Sasak dinamakan begawe atau kenduri. Proses ini diawali oleh 6) rebaq pucuk atau musyawarah keluarga dari kedua belah pihak dalam rangka penyelesaian adat selanjutnya. Setelah ada kesepakatan barulah dilanjutkan dengan acara 7) sorong serah atau nyongkolan atau nyombe, yaitu tradisi menjenguk ke rumah pihak pengantin perempuan yang sebelumnya diawali oleh prosesi adat. Sebelum nyongkolan dilaksanakan, diawali dengan acara sorong serah di tempat pengantin wanita, baik pihak laki-laki atau perempuan masing-masing memiliki pemangku adat yang tugasnya melaksanakan aji krama sorong serah. Selesai upcara adat sorong serah barulah penganting diarak dengan untuk acara nyongkolan.

Setelah proses sorong serah dan nyonglolan dilanjutkan dengan proses terakhir yaitu bales lampak nae, yaitu sebuah prosesi yang melambangkan silaturahmi dan persaudaraan yang tidak luput dari khilaf dan kesalahan, sehingga melalui proses ini diharapkan dapat disucikan.

Adat sorong serah itu sendiri memiliki proses yang khusus dalam pelaksanaannya, karena perlu beberapa perangkat yang menjadi kebutuhan dalam pelaksanaannya. Perangkat yang dibutuhkan dalam proses sorong serah adalah:

- Olen: seperangkat kain tenun sebagai lambang bahwa pengantin laki-laki telah siap untuk memberikan kebutuhan sandang bagi istrinya.

- Tampak lemah: seperangkat perlatan yang melambangkan bahwa kesiapan pengantin laki-laki dalam memberikan kebutuhan akan pangan atau makanan.

- Pemuput/pemegat: sejumlah uang untuk para saksi adat.

- Sesirah: biasa juga disebut otak bebeli, biasanya berupa kain putih dan hitam yang diikat dengan benang kasur, bermakna sebagi ikatan yang tidak terpisahkan.

- Salin dedeng: sejumlah peralatan dapur, ditambah dengan kain dan mukena sebagai lambang pengganti kasih sayang ibu atau air susu ibu.

- Sedah lanjaran: yaitu berupa seperangkat buah pinang dan rokok khas suku Sasak dari tembakau yang digulung dengan kulit jagung.

\subsection{Perkawinan Suku Samawa}

Dalam adat istiadat perkawinan Sumbawa secara keseluruhan ada banyak hal yang harus dipersiapkan. Perkawinan bukanlah perhelatan yang gampang dilaksanakan 
LINGUA, Vol. 15, No. 2, September 2018

p ISSN: 1979 9411; e ISSN: 2442 238X

Http://lingua.pusatbahasa.or.id; Email:presslingua@gmail.com

Center of Language and Culture Studies, Surakarta, Indonesia

Rosana, Nana; Mahyuni \& Burhanuddin. 2018. Estetika Resepsi Bahasa Sasak para Pembayun

dalam Upacara Adat Sorong Serah Masyarakat Sasak di pulau Lombok.

Lingua (2018), 15(2):187 206. DOI:10.30957/lingua.v15i2.526.

menurut masyarakat Sumbawa. Perkawinan adalah upacara besar yang harus dipikirkan dan dipersiapkan sebaik mungkin oleh kedua belah pihak terutama oleh keluarga perempuan.

Seorang gadis dan pemuda yang memang dianggap sudah pantas untuk menikah akan diperhatikan oleh keluarga. Jika sepasang muda-mudi mengatakan pada kedua orang tua siap menikah maka mulailah proses adat dimulai. Berawal dari 1) bajajak yaitu proses diutusnya dua atau tiga orang yang dituakan dalam keluarga laki-laki untuk menemui keluarga perempuan dan menanyakan apakah perempuan tersebut telah dilamar seseorang atau sudah ada yang punya? Jika jawaban dari keluarga perempuan mengisyaratkan bahwa ia belum dilamar atau dimiliki siapapun, maka proses adat perkawinan akan terus dilangsungkan.

Berangkat dari jawaban dalam proses bajajak upacara dilanjutkan pada proses 2) bakatoan atau meminang. Pada dasarnya budaya meminang dalam masyarakat Sumbawa sama dengan budaya meminang masyarakat lainnya. Namun, yang membedakan mungkin hanya kalimat-kalimat yang diucapkan. Terkadang digunakan pantun-pantun Sumbawa untuk menyampaikan maksud dan tujuan kedatangan demikian pula keluarga perempuan yang menerima.

Jika bakatoan telah dilaksanakan dan dinyatakan diterima dengan baik, maka upacara dilanjutkan pada basaputis. 3) Basaputis adalah kegiatan yang digunakan oleh kedua belah pihak (keluarga) untuk membicarakan bagaimana acara perkawinan yang diinginkan, seberapa besar biaya yang dibutuhkan. Terutama seberapa banyak barang dan besarnya uang yang harus ditanggung pihak laki-laki dalam upacara tersebut.

Biasanya dalam upacara itu dibawalah sebuah cincin emas sebagai tanda putus atau tanda diterimanya kesepakatan dan upacara akan dilanjutkan pada prosesi berikutnya. Pada prosesi basaputis ini pula kedua keluarga yang biasanya dibantu sandro 'dukun' memutuskan kapan upacara baiknya dilaksanakan. Tepatnya kapan rangkaian prosesi lainnya digelar.

Prosesi berikutnya adalah 4) badaq yaitu prosesi pemberitahuan kepada si gadis dengan siapa ia akan dikawinkan. Pemberitahuan ini umumnya dilakukan oleh perempuan yang dianggap sepuh dalam keluarga tersebut. Biasanya si perempuan calon pengantin akan menangis mengenang masa muda yang akan segera berakhir. Pada prosesi ini para gadis dari tetangga dan kerabat akan datang untuk memukul rantok (lumping kayu untuk menumbuk padi). Akan terdengar riuh dan sorak sorai yang menjadi pertanda pada khalayak bahwa si calon pengantin telah mengetahui dirinya akan dikawinkan dengan seorang laki-laki.

Prosesi berikutnya adalah 5) nyorong yaitu prosesi keluarga laki-laki menghantarkan segala kebutuhan untuk perkawinan yang telah disepakati bersama pada prosesi basaputis. Pada peristiwa inilah akan terlihat penggunaan pantun Sumbawa atau yang disebut lawas digunakan oleh keluarga kedua belah pihak untuk saling berbalasan.

Setelah prosesi ini dilanjutkan dengan prosesi utama dan yang sangat ditunggu oleh semua keluarga yaitu prosesi Basai. 6) Basai adalah proses akad nikah yang dilanjutkan dengan resepsi. Saat ini perkawinan di Sumbawa sering memadukan akad nikah dengan acara resepsi. 
Ekspresi verbal dalam bahasa yang digunakan pada saat perkawinan adat Suku Samawa terlihat pada cuplikan berikut.

Pihak laki-laki:

Batamu kusorong bangka

Balabu ling sinding sia

Bongkar kebawa kemas gamana

Terjemahan

Datang diibaratkan perahu besar

Mampir didarmaga

Ambil muatan dengan senyum

Jawaban pihak perempuan :

Kadatang sangka kuangkang

Muleku santurit kemang

Lema mampis bawa rungan

Terjemahan

Anda datang dari depan

Pulang dengan membawa kenangan yang baik

Untuk diinformasikan kepada masyarakat banyak

\subsection{Semiotik}

Semiotik (semiotika) adalah ilmu tentang tanda-tanda. Ilmu ini mengenggap bahwa fenomena sosial/masyarakat dan kebudayaan itu merupakan tanda-tanda. Semiotik itu mempelajari sistem-sistem, aturan-aturan, dan konvensi-konvensi yang memungkinkan tanda-tanda tersebut mempunyai arti. Dalam lapangan kritik sastra, penelitian semiotik meliputi analisis sastra sebagai sebuah penggunaan bahasa yang bergantung pada (ditentukan) konvensi-konvensi tambahan dan meneliti ciri-ciri (sifatsifat) yang menyebabkan bermacam-macam cara wacana mempunyai makna (Preminger, 1974:980 dalam Pradopo, 2007:119).

Semiotik adalah ilmu atau metode analisis untuk mengkaji tanda (Hoed, 1992:2). Tanda adalah sesuatu yang memiliki sesuatu yang lain dapat berupa pengalaman, pikiran, perasaan, gagasan, dan lain-lain. Jadi, yang dapat menjadi tanda sebenarnya bukan hanya bahasa, melainkan berbagai hal yang melingkupi kehidupan ini, walau harus diakui bahwa bahasa adalah sistem tanda yang paling lengkap dan sempurna. Tanda-tanda itu berupa gerakan anggota badan, gerakan mata, mulut, bentuk tulisan, warna, bendera, bentuk dan potongan rumah, pakaian, karya seni : sastra, lukis, patung, film, tari, musik, dan lain-lain yang berada di sekitar kehidupan kita. Dengan demikian teori semiotik bersifat multidisiplin, sebagaimana diharapkan Peirce agar teorinya bersifat umum dan dapat diterapkan pada segala macam tanda. Semiotik dapat 
LINGUA, Vol. 15, No. 2, September 2018

p ISSN: 1979 9411; e ISSN: 2442 238X

Http://lingua.pusatbahasa.or.id; Email:presslingua@gmail.com

Center of Language and Culture Studies, Surakarta, Indonesia

Rosana, Nana; Mahyuni \& Burhanuddin. 2018. Estetika Resepsi Bahasa Sasak para Pembayun

dalam Upacara Adat Sorong Serah Masyarakat Sasak di pulau Lombok.

Lingua (2018), 15(2):187 206. DOI:10.30957/lingua.v15i2.526.

diterpakan pada (atau: menjadi bidang garapan) linguistik, seni (dengan berbagai subdisiplinnya), sastra, film, filsafat, antropologi, arkeologi, arsitektur, dan lain-lain.

Dasar segala sesuatu yang dapat diamati atau dibuat teramati dapat disebut tanda. Karena itu, tanda tidaklah terbatas pada benda. Adanya peristiwa, tidak adanya peristiwa, struktur yang ditemukan adalah sesuatu, suatu kebiasaan, semua ini dapat disebut benda. Sebuah bendera kecil, sebuah isyarat tangan, sebuah kata, suatu keheningan, suatu kebiasaan makan, sebuah gejala mode, suatu gerak syaraf, peristiwa memerahnya wajah, suatu kesukaan tertentu, letak bintang tertentu, suatu sikap, setangkah bunga, rambut uban, sikap diam membisu, gagap. Bicara cepat, berjalan sempoyongan, menatap, api, putih, bentuk bersudut tajam, kecepatan, kesabaran, kegilaan, kekhawatiran, kelengahan semuanya itu dianggap sebagai tanda (http://sigodang.blogspot.com/2008/11/sejarah-semiotika.html).

Teori semiotik merupakan teori yang digunakan untuk menemukan makna tanda dan lambang yang dipergunakan dalam suatu wacana. Telaah wacana yang bersifat semiotik merupakan sistem tanda-tanda dan menentukan konvensi-konvensi apa yang memungkinkan wacana tersebut mempunyai arti (Abraham dalam Pradopo, 2007:2).

Semiotika merupakan ilmu yang mempelajari tentang tanda. Konsep tanda ini melihat bahwa makna muncul ketika ada hubungan yang bersifat asosiasi atau in absentia antara yang ditandai (signified) dan yang menandai (signifier). Tanda adalah kesatuan dari suatu bentuk penanda (signifier) dengan sebuah ide atau petanda (signified). Dengan kata lain, penanda adalah "bunyi yang bermakna" atau "coretan yang bermakna".

Dalam pemaknaan karya sastra menurut Pradopo (2007: 4) ada tiga tanda yang memegang peranan penting. Ketiga tanda itu adalah:

a. Ikon merupakan tanda antara petanda dan penanda sama atau menyatakan hubungan yang bersifat alamiah. Misalnya kata gambar, potret, patung hewan (penanda) sama dengan hewan yang ditandai.

b. Indeks ialah tanda yang penanda menyatakan adanya hubungan kausalitas seperti asap menandai api atau mendung menandai hujan.

c. Simbol adalah tanda yang petandanya tidak menunjukkan adanya hubungan alamiah, hubungan arbetrer berdasarkan konvensi seperti kata ibu (petanda) menandai orang yang melahirkan.

Reprentasi ikon ini ditandai dengan kemiripan. Contohnya, foto calon anggota legislatif dalam kertas suara ataupun gambar yang banyak tersebar di jalan raya saat berlangsungnya pemilu adalah sebuah ikon. Model tanda objek interpretant dari Pierce merupakan sebuah ikon dalam upayanya mereproduksi dalam konkret struktur relasi yang abstrak di antara unsur-unsurnya. Dapat pula dikatakan sebagai ikon atau tanda yang memiliki ciri yang sama dengan apa yang dimaksudkan. Misalnya: Foto atau gambar Soekarno adalah sebagai ikon seorang presiden pertama di Indonesia atau bapak orator indonesia. Peta Indonesia adalah ikon dari wilayah Indonesia yang tergambar dalam peta tersebut. Cap jempol Soekarno adalah ikon dari ibu jari presiden pertama Indonesia. 
LINGUA, Vol. 15, No. 2, September 2018

p ISSN: 1979 9411; e ISSN: 2442 238X

Http://lingua.pusatbahasa.or.id; Email:presslingua@gmail.com

Center of Language and Culture Studies, Surakarta, Indonesia

Rosana, Nana; Mahyuni \& Burhanuddin. 2018. Estetika Resepsi Bahasa Sasak para Pembayun

dalam Upacara Adat Sorong Serah Masyarakat Sasak di pulau Lombok.

Lingua (2018), 15(2):187 206. DOI:10.30957/lingua.v15i2.526.

Indeks adalah tanda yang memiliki hubungan sebab-akibat dengan apa yang diwakilinya. Atau disebut tanda sebagai suatu bukti. Contohnya: asap dan api, asap akan menunjukkan adanya api disekitarnya. Jejak telapak kaki di tanah merupakan tanda indeks orang yang melewati tempat itu. Tanda tangan (signature) adalah indeks dari keberadaan seseorang yang menoreh tanda tangan tersebut. Simbol merupakan tanda berdasarkan konvensi, peraturan atau perjanjian yang disepakati bersama.

Simbol baru dapat dipahami jika seseorang sudah mengerti arti yang telah disepakati bersama. Simbol baru dapat dipahami jika seseorang sudah mengerti arti yang telah disepakati sebelumnya. Contohnya: Garuda Pancasila bagi bangsa Indonesia adalah burung yang memiliki perlambang yang kaya makna. Namun bagi orang yang memiliki latar budaya yang berbeda, seperti orang eskimo, Garuda Pancasila akan dianggap sebagai burung yang biasa saja yang disamakan dengan burung-burung sejenis elang lainnnya. Mengacu pada teori di atas, penelitian ini sangat tepat jika objek kajiannya adalah tanda-tanda yang terdapat pada perkawinan adat dua suku yaitu perkawinan adat suku Sasak dan Samawa yang berupa tanda-tanda dalam gerakan lisan, gerakan benda atau material, dan tanda-tanda pada irama atau musik tradisional.

\section{METODE}

\subsection{Pendekatan}

Penelitian ini menggunakan pendekatan deskriptif kualitatif. Data yang dicatat berupa perian bahasa yang biasa dikatakan sifatnya seperti potret atau paparan seperti apa adanya (Sudaryanto, 1992:62 dalam Muhammad, 2011:180). Jenis penelitian ini ialah etnografi dan bertumpu pada informan kunci atau orang-orang yang mengetahui dan dapat menyediakan pengertian yang kaya ke dalam budaya dari kelompok dan isuisu yang dimaksudkan dalam studi (Emzir, 2010:19). Penelitian etnografi dianggap cocok karena berusaha meneliti suatu kelompok kebudayaan tertentu berdasarkan pengamatan dan kehadiran peneliti di lapangan. Peneliti melakukan pengamatan terhadap perkawinan adat Suku sasak dan Suku Samawa, baik prosesi, tanda-tanda, dan fungsi dalam perkawinan adat kedu suku.

Penelitian ini telah dilakukan di kabupaten Lombok Timur untuk pulau Lombok dan kabupaten Sumbawa Besar untuk pulau Sumbawa. Pemilihan lokasi penelitian berdasarkan tempat kedua suku berdomisili. Lokasi penelitian ialah Desa Montong Betok Kecamatan Montong Gading Kabupaten Lombok Timur untuk mengamati perkawinan adat Suku Sasak. Di Pulau Sumbawa observasi dilakukan di Desa Plampang Kecamatan Plampang. Pemilihan lokasi ini berdasarkan hasil pengamatan sementara peneliti dan terkait dengan informan yang menjadi narasumber serta masyarakat yang langsung menjadi subjek penelitian.

\subsection{Data dan Sumber Data}

Data penelitian adalah acara perkawinan adat suku Sasak di Lombok dan Suku Samawa di Sumbawa. Sumber data diperoleh melalui proses perkawinan adat Suku Sasak di Lombok dan Suku Samawa di Sumbawa, di samping melalui informan yang merupakan tokoh adat pada kedua suku. Informan penelitian ini adalah orang asli Suku 
LINGUA, Vol. 15, No. 2, September 2018

p ISSN: 1979 9411; e ISSN: 2442 238X

Http://lingua.pusatbahasa.or.id; Email:presslingua@gmail.com

Center of Language and Culture Studies, Surakarta, Indonesia

Rosana, Nana; Mahyuni \& Burhanuddin. 2018. Estetika Resepsi Bahasa Sasak para Pembayun

dalam Upacara Adat Sorong Serah Masyarakat Sasak di pulau Lombok.

Lingua (2018), 15(2):187 206. DOI:10.30957/lingua.v15i2.526.

Sasak dan Samawa yang merupakan tokoh adat dan mengerti serta kompeten dalam acara perkawinan Suku Sasak dan Suku Samawa.

Informan penelitian ini adalah tokoh adat, tokoh agama, budayawan, dan masyarakat yang sedang melakukan proses perkawinan adat pada kedua suku. Pemilihan tokoh adat, tokoh, agama, budayawan, dan masyarakat pelaku proses perkawinan dimaksudkan agar pemerolehan data menjadi lebih cepat dan akurat. Tokoh, adat, tokoh, agama, budayawan, dan masyarakat pelaku proses perkawinan pada saat penelitian merupakan sumber data yang dapat dipertaanggunjawabkan. Adapun nara sumber untuk mendapatkan data tentang proses perkawinan adat berjumlah 8 orang, 4 orang dari Suku Sasak dan 4 orang dari Suku Samawa. Kedelapan orang yang menjadi nara sumber adalah mereka yang tahu dan mengerti tentang perkawinan adat dan berbagai unsur sesuai dengan kajian yang dilakukan.

\subsection{Teknik Pengumpulan Data}

\subsubsection{Observasi}

Observasi dalam penelitian ini bertujuan untuk mengamati secara langsung objek penelitian, aspek-aspek perilaku yang dalam perkawinan adat Suku Sasak di Lombok dan Suku Samawa di Sumbawa, sehingga dapat memahami perilaku yang menjadi objek perkawinan untuk mengetahui dan mengkaji prosesi, tanda-tanda, dan fungsi dalam perkawinan adat Suku Sasak di Lombok dan Suku Samawa di Sumbawa.

Observasi dilakukan pada daerah penelitian dengan melakukan pengamatan langsung terhadap proses perkawinan adat Suku Sasak dan Suku Samawa. Pengamatan dilakukan peneliti secara langsung dengan mengambil rekaman data melalui format penelitian yang telah disiapkan. Pengamatan yang dilakukan sesuai dengan objek kajian yaitu mengamati ekspresi verbal yang muncul pada perkawinan adat Suku Sasak dan Suku Samawa. Di samping mengamati ekspresi verbal, pengamatan juga dilakukan terhadap simbol, tanda, nilai, dan fungsi dari perkawinan adat kedua suku. Beberapa unsur yang menjadi objek observasi peneliti, antara lain.

- Bahasa yang dipergunakan dalam proses perkawinan adat Suku Sasak dan Suku Samawa.

- Proses perkawinan adat Suku Sasak dan Suku Samawa.

- Simbol dan tanda dalam perkawinan adat Suku Sasak dan Samawa

- Nilai-nilai budaya dalam perkawinan adat Suku Sasak dan Suku Samawa.

\subsubsection{Wawancara}

Intervieu yang sering juga disebut dengan wawancara atau kuesioner lisan, adalah sebuah dialog yang dilakukan oleh pewawancara (interviewer) untuk memperoleh informasi dari terwawancara (interviewer) (Arikunto, 2006:155). Wawancara harus mempunyai tujuan tertentu agar tidak menjadi suatu percakapan yang tidak sistematis atau melakukan pengamatan yang tidak mempunyai ujung pangkal. Oleh karen itu, peneliti yang melakaukan wawancara mempunyai tiga kewajiban, yaitu:

- Memberi tahu informan tentang hakikat penelitian dan pentingnya kerjasama mereka dengan peneliti; 
- Menghargai informan atas kerjasamanya; dan

- Memperoleh informasi dan data yang diinginkan (Emzir, 2010:50)

Wawancara yang dilakukan adalah gabungan antara wawancara tertutup dan terbuka, hal ini dilakukan karena jawaban yang diinginkan tidak hanya jawaban "ya atau tidak", tetapi jawaban dari informan yang diharapkan juga berupa pendapat dan pengetahuan tentang perkawinan adat Suku sasak dan Suku Samawa. Tokoh yang diwawancarai dari masing-masing suku adalah orang yang memahami tentan perkawinan adat pada kedua suku.

\subsection{Penganalisisan Data}

Analisis berarti kategorisasi, penataan, manipulasi, dan peringkasan data untuk memperoleh jawaban atas pertanyaan penelitian. Kegunaan analisis ialah mendiskusikan data menjadi perwujudan yang dapat dipahami dan ditafsir dengan cara tertentu hingga relasi masalah penelitian dapat ditelaah serta diuji (Kerlinger, 2006:218).

Sebagai acuan dalam penganalisisan data penelitian ini dipergunakan Model Miles dan Huberman, yang terdiri dari tiga kegiatan, yaitu (1) reduksi data; (2) penyajian data; dan (3) penarikan/verifikasi kesimpulan. Reduksi data, meliputi proses pemilihan, pemokusan, penyederhanaa, abstraksi, dan pentranformasian "data mentah" yang didapat dari hasil observasi dan interview serta perekaman yang diperoleh dari catatan lapangan. Proses selanjutnya dalah merangkum, mengkode, membuat catatan, selanjutnya diverifikasi untuk mendaptkan gambaran tentang perkawinan adat kedua suku. Instrumen yang digunakan dalam penelitian sederhana ini kecuali peneliti sendiri, juga digunakan handy cam/kamera digital untuk merekam selama terjadinya proses komunikasi, dan alat pencatat yang digunakan setelah perekaman berlangsung.

Data secara keseluruhan dianalisis dengan menggunakan teknik analisis daskriptif kualitatif model Miles dan Huberman. Langkah yang dilakukan adalah data yang berupa rekaman ditranskripsikan ke dalam bentuk tulisan. Data dianalisis dengan metode kualitatif melalui tahapan-tahapan sebagai berikut.

- Transkripsi data dari handycam/kamera/handphone ke dalam komputer.

- Perangkuman dan tabulasi data yang berisi tentang tata cara perkawinan adat atau suara/bunyi bahasa yang digunakan.

- Analisis data secara deskriptif kemudian interpretasi atas hasil analisis.

- Penarikan kesimpulan.

\section{HASIL DAN BAHASAN}

\subsection{Bentuk ekspresi verbal}

\subsubsection{Ekspresi verbal perkawinan Suku Sasak}

Ekspresi verbal ialah pernyataan lisan terutama saat peristiwa berlansung yang merefleksikan ekspresi verbal dalam perkawinan adat Suku Sasak dan Suku Samawa. Bentuk ekspresi verbal terlihat pada dialog antara pengemban adat ketika akan berlangsung sorong serah aji krama. Pengemban adat dalam upacara perkawinan dikenal dengan pisolo atau pembayun. 
Perkawinan adat Suku Sasak yang memiliki rangkaian upacara sorong serah aji krama, berlangsung setelah proses ijab kabul. Tidak semua orang dapat menjadi pisol atau pembayun, mereka adalah orang pilihan dari majelis adat yang telah terlatih untuk mengemban upacara adat. Pisolo berasal dari dua belah pihak, pisolo penyerah berasal dari utusan keluarga pengantin pria dan pisolo penampi berasal dari utusan keluarga pengantin wanita.

Pisolo penyerah biasanya diikuti oleh beberapa orang yang akan menjadi saksi dalam upacara sorong serah, dengan membawa seperangkat alat yang akan dipergunakan. Pisolo penyerah berjalan menuju tempat digelarnya acara adat sorong serah aji krama yaitu di kediaman keluarga pengantin wanita.

Acara sorong serah yang akan dilaksanakan dan disaksikan oleh masyarakat banyak, pengembang adat dari pengantin wanita menyiapkan tempat untuk menyambut pengemban adat dari pengantin pria. Pengemban adat pengantin pria dinamakan pisolo penampi, tugasnya mewakili keluarga pengantin dalam menerima pisolo penyerah yang berasal dari pengantin pria.

Berikut cuplikan dialog antara pisolo penyerah dari pengantin pria dan pisolo penampi dari pengantin wanita.

Bahasa Pisolo Penyerah

\begin{tabular}{|c|c|}
\hline Bahasa Sasak Madya & Bahasa Indonesia \\
\hline Bismillahirrohmanirrohim & Bismillahirrahmanirrohim \\
\hline $\begin{array}{l}\text { Saka tahing pamuji mantuk maring Allah } \\
\text { kang hamur ben jagat kang honang gine } \\
\text { sinembah lan pinuji ora lian among Allah } \\
\text { sa tunggal. }\end{array}$ & $\begin{array}{l}\text { Pertama-tama marilah kita panjatkan puji } \\
\text { syukur kepada Allah yang telah } \\
\text { menciptakaan bumi beserta segala isinya, } \\
\text { Dia lah Tuhan yang pantas kita sembah dan } \\
\text { puji, Tuhan Yang Kuasa dan Esa. }\end{array}$ \\
\hline $\begin{array}{l}\text { Ring dine langsonten puniki, deweg titiang } \\
\text { pulih panggih jarwe lan jinarwe. }\end{array}$ & $\begin{array}{l}\text { Pada sore hari ini, saya datang menemui } \\
\text { saudara sekalian untuk bertatap muka secara } \\
\text { langsung. }\end{array}$ \\
\hline $\begin{array}{l}\text { Moga mogi pepanggihan puniki dados } \\
\text { purun akrab hangelis tias kelawan ragan } \\
\text { dane sami. }\end{array}$ & $\begin{array}{l}\text { Semoga kedatangan saya ini dapat diterima } \\
\text { dengan baik, sehingga apa yang akan kami } \\
\text { sampaikan segera selesai. }\end{array}$ \\
\hline $\begin{array}{l}\text { Sadurung deweg titiang jembaring atur } \\
\text { maring dane-dane sami, mapan deweg } \\
\text { titiang jalmi mukminin kimut maring } \\
\text { syare'at Nabi Muhammad SAW, boten lali } \\
\text { deweg titiang ngasung salam ugami. }\end{array}$ & $\begin{array}{l}\text { Sebelumnya, saya sampaikan kepada } \\
\text { saudara sekalian, karena kita sebagai umat } \\
\text { Nabi Muhammad yang menjalankan syariat } \\
\text { saya menyampaikan salam agama... }\end{array}$ \\
\hline $\begin{array}{l}\text { Assalamualaikum } \quad \text { Warohmatullahi } \\
\text { Wabarokatuh }\end{array}$ & $\begin{array}{l}\text { Assalamualaikum } \\
\text { Wabaraktuh }\end{array}$ \\
\hline
\end{tabular}

Bahasa verbal pisolo penyerah di atas, memiliki struktur bahasa dan nilai tinggi. Bahasa pisolo penyerah dalam menyampaikan keinginan kepada pisolo penampi didengar oleh banyak orang, namun tidak semua yang mendengar memahaminya. Pada 
LINGUA, Vol. 15, No. 2, September 2018

p ISSN: 1979 9411; e ISSN: 2442 238X

Http://lingua.pusatbahasa.or.id; Email:presslingua@gmail.com

Center of Language and Culture Studies, Surakarta, Indonesia

Rosana, Nana; Mahyuni \& Burhanuddin. 2018. Estetika Resepsi Bahasa Sasak para Pembayun

dalam Upacara Adat Sorong Serah Masyarakat Sasak di pulau Lombok.

Lingua (2018), 15(2):187 206. DOI:10.30957/lingua.v15i2.526.

awal pelaksanaan upacara adat sorong serah aji krama dimulai dengan salam, selanjutnya memanjatkan rasa syukur dengan ucapan "Saka tahing pamuji mantuk maring Allah". Kata "saka" berarti pertama atau dapat diartikan tunggal, namun untuk memperhalus diberikan sandangan "tahing" sehingga menjadi sebuah kata "saka tahing" yang berarti pertama-tama. Kata "saka tahing" merupakan kata majemuk yang dalam percakapan sehari-hari masyarakat Suku Sasak tidak dijumpai penggunaan kata tersebut.

Lanjutan dari kalimat di atas, pisolo penyerah berkata "pamuji mantuk maring Allah". Jik mengandung arti segala puji bagi Allah. Kata pamuji dalam bahasa Sasak disebut "puji". Selanjutnya kata "mantuk" memiliki arti pulang, tetapi dalam konteks tersebut bermakna "pada atau segala". Kata "maring" berarti bagi atau pada, dalam bahasa Sasak dikatakan "tipaq", sedangkan kata "Allah" berdiri sendiri.

Apabila kalimat "pamuji mantuk maring Allah" dipisahkan dalam pengucapannya maka akan sulit dimaknai. Strukur kata yang sudah memiliki keterikatan dengan kata lainnya menjadikan sebuah kalimat yang terstrukur, kalimat tersebut teridiri dari dua kata bentukan yaitu "pamuji mantuk" (segala puji) dan "maring Allah" (bagi Allah), kedua kata tersebut merupakan kata majemuk.

Kalimat berikutnya dari pisolo penyerah "kang hamur ben jagat kang honang gine sinembah lan pinuji ora lian among Allah sa tunggal". (yang telah menciptakaan bumi beserta segala isinya, Dia lah Tuhan yang pantas kita sembah dan puji, Tuhan Yang Kuasa dan Esa). Apabila diuraikan kalimat tersebut menjadi kata per kata, maka akan menjadi sebuah kalimat yang rancu. Penggunaan kata dalam kalimat oleh pisolo dalam upacara adat sorong serah aji krama pada perkawinan adat Suku Sasak menunjukkan adanya ekspresi verbal yang sangat tinggi dari sifatnya. Kata-kata yang dipergunakan banyak yang sifatnya sebagai penghormatan kepada lawan bicara.

Selanjutnya pada kalimat "Ring dine langsonten puniki, deweg titiang pulih panggih jarwe lan jinarwe" (Pada sore hari ini, saya datang menemui saudara sekalian untuk bertatap muka secara langsung). Kata "ring" (pada, saat), "dine" (ini), "langsonten"(sore), "puniki" (di sini). Ketika kalimat "ring dine langsonten puniki" diurai terlihat bahwa sangat sulit dimaknai secara lugas, sehingga kata "ring dine" pada kalimat tersebut harus menjadi satu. Bentuk yang lain terlihat juga pada kalimat "deweg titiang pulih panggih jarwe lan jinarwe". Kata "deweg titiang" (saya) merupakan satu kata yang tidak berdiri sendiri, sama halnya dengan kata "pulih panggih" (dapat datang), "jarwe lan jinarwe" (bertemu dan bertatap muka).

Kalimat berikutnya "Moga mogi pepanggihan puniki dados purun akrab hangelis tias kelawan ragan dane sami". (Semoga kedatangan saya ini dapat diterima dengan baik, sehingga apa yang akan kami sampaikan segera selesai). Kata-kata pisolo dalam kalimat tersebut merupakan kata penghormatan yang tinggi untuk lawan bicara, kata "moga mogi" (semoga) sebenarnya bisa saja cukup dengan kata "moga" yang maknanya sama yaitu semoga, akan tetapi dalam upacara adat dipergunaka kata-kata yang memiliki nilai tinggi. Para pisolo dalam menyebutkan diri atau orang lain saja harus dilengkapi dengan kata sandang, misalnya kata "deweg titiang", yang sesungguhnya kata "deweg dan titiang” memiliki arti sama yaitu saya. Menyebut orang 
lain atau lawan bicara dengan kata "ragandane" (kamu) yang secara harfiah kata "raga" berarti tubuh, tetapi untuk penghormatan dipergunakan "ragandande".

Kalimat terakhir sebagai pembuka dalam acara adat sorong serah aji krama adalah "Sadurung deweg titiang jembaring atur maring dane-dane sami, mapan deweg titiang jalmi mukminin kimut maring syare'at Nabi Muhammad SAW, boten lali deweg titiang ngasung salam ugami. Assalamualaikum Warohmatullahi Wabarokatuh". (Sebelumnya, saya sampaikan kepada saudara sekalian, karena kita sebagai umat Nabi Muhammad yang menjalankan syariat saya menyampaikan salam agama...Assalamualaikum Warahmatullahi Wabaraktuh)

Kebesaran jiwa dari seorang pisolo dalam menyampaikan kalimat dengan bahasa yang sangat halus tergambar pada kalimat akhir dari acara adat perkawinan Suku Sasak di Pulau Lombok. Untuk mengucapkan salam, pisolo meminta ijin terlebih dahulu kepada semua orang yang menyaksikan acara sorong serah aji krama.

Bahasa Pisolo Penyerah

\begin{tabular}{|c|c|}
\hline Bahasa Sasak Madya & Bahasa Indonesia \\
\hline $\begin{array}{l}\text { Waalaikumsalam } \\
\text { Wabarokatuh }\end{array}$ & $\begin{array}{l}\text { Wassalamualaikum } \\
\text { Wabarakatuh }\end{array}$ \\
\hline $\begin{array}{l}\text { Patut kalintang patut pangandike } \\
\text { ragandane saniwawu mapan deweg } \\
\text { titiang lan dane-dane hingkang } \\
\text { nungguh ring upakare punniki jalmi } \\
\text { mu'minin kinut maring syre'at Nabi } \\
\text { Muhammad SAW, punniki deweg titiang } \\
\text { hangangsul salam ugami ragandane. }\end{array}$ & $\begin{array}{l}\text { Sudah sepantasnya kami menerima } \\
\text { pembicaraan dari saudara, dan saudara } \\
\text { sekalian yang duduk di tempat upacara } \\
\text { adat ini. Sebagai umat nabi Muhammad } \\
\text { saya terima salam agama yang } \\
\text { disampaikan. }\end{array}$ \\
\hline Dawe & In tujuan saudara \\
\hline
\end{tabular}

Menanggapi apa yang disampaikan pisolo penyerah yang merupakan wakil dari keluarga pengantin pria, pisolo penampi sebagai wakil pihak keluarga pengantin wanita dengan bahasa yang sama memberikan jawaban.

Waalaikumsalam Warrohmatullahi Wabarokatuh, Patut kalintang patut pangandike ragandane saniwawu mapan deweg titiang lan dane-dane hingkang nungguh ring upakare punniki jalmi mu'minin kinut maring syre'at Nabi Muhammad SAW, punniki deweg titiang hangangsul salam ugami ragandane. Daweg, kodal pangandike malih.

Kalimat "patut kalintang patut pangandike ragandane" (sudah sepantasnya kami menerima pembicaraan saudara). Kalimat tersebut dapat pula dimaknai sudah sewajarnya saya menerima pembicaraan saudara. Bentuk eskpresi verbal dari komunikasi antara pengemban adat dalam upacara perkawinan adat Suku Sasak tidak 
hanya dari struktur bahasanya, melainkan juga dari intonasi, vokal, dan ekspresi nonverbal yang muncul.

\subsubsection{Ekspresi verbal perkawinan Suku Samawa}

Proses perkawinan adat Suku Samawa dimulai sejak sepasang muda-mudi mengatakan pada kedua orang tua siap menikah. Berawal dari Bajajak yaitu proses diutusnya dua atau tiga orang yang dituakan dalam keluarga laki-laki untuk menemui keluarga perempuan dan menanyakan apakah perempuan tersebut telah dilamar seseorang atau sudah ada yang punya? Jika jawaban dari keluarga perempuan mengisyaratkan bahwa ia belum dilamar atau dimiliki siapapun, maka proses adat perkawinan akan terus dilangsungkan.

Berangkat dari jawaban dalam proses Bajajak upacara dilanjutkan pada proses Bakatoan atau meminang. Pada dasarnya budaya meminang dalam masyarakat Sumbawa sama dengan budaya meminang masyarakat lainnya. Yang membedakan kalimat-kalimat yang diucapkan, terkadang digunakan pantun-pantun Sumbawa untuk menyampaikan maksud dan tujuan kedatangan demikian pula keluarga perempuan yang menerima. Berikut kata-kata yang biasa digunakan untuk melakukan prosesi bakatoan:

Pihak laki-laki:

\begin{tabular}{|l|l|}
\hline \multicolumn{1}{|c|}{ Bahasa Sumbawa } & \multicolumn{1}{|c|}{ Bahasa Indonesia } \\
\hline nan si hajat kamita bua kami datang & Maksud kedatangan kami untuk \\
perisia lakota, sate tu sambung & bertemu dengan anda, kami mau \\
silaturrahmi anak kami........ ke anak & menyambung silaturrahmi antara anak \\
sia ......... & kami ....... dengan anak anda ......... \\
\hline
\end{tabular}

Pihak perempuan:

\begin{tabular}{|l|l|}
\hline \multicolumn{1}{|c|}{ Bahasa Sumbawa } & \multicolumn{1}{|c|}{ Bahasa Indonesia } \\
\hline $\begin{array}{l}\text { lamin nan merua luk balong, kutarima } \\
\text { hajat sia (jika lamaran diterima) }\end{array}$ & $\begin{array}{l}\text { Kalau itu yang terbaik untuk kita } \\
\text { semua, kami menerima dengan senang } \\
\text { hati. }\end{array}$ \\
$\begin{array}{l}\text { Kle apa-apa ling sia, kueneng sia } \\
\text { datang karing sekali po, maklum sate } \\
\text { tu ramada' lako serea keluarga ahli } \\
\text { waris ade ada ninta (jika lamaran } \\
\text { ditunda) }\end{array}$ & $\begin{array}{l}\text { Dengan penuh hormat, anda datang } \\
\text { lagi sekali saja, karena kami mau } \\
\text { memberitahu keluarga dekat kami } \\
\text { terlebih dahulu. }\end{array}$ \\
\hline
\end{tabular}

Jika Bakatoan telah dilaksanakan dan ternyata diterima dengan baik, maka upacara dilanjutkan pada Basaputis. Basaputis adalah kegiatan dalam upacara perkawinan masyarakat Sumbawa yang digunakan oleh kedua keluarga belah pihak untuk membicarakan bagaimana acara perkawinan yang diinginkan, seberapa besar 
biaya yang dibutuhkan. Terutama seberapa banyak barang dan besarnya uang yang harus ditanggung pihak laki-laki dalam upacara tersebut.

Biasanya dalam upacara itu dibawalah sebuah cincin emas sebagai tanda putus atau tanda diterimanya kesepakatan dan upacara akan dilanjutkan pada prosesi berikutnya. Pada prosesi Basaputis ini pula kedua keluarga yang biasanya dibantu Sandro 'dukun' memutuskan kapan upacara baiknya dilaksanakan. Tepatnya kapan rangkaian prosesi lainnya digelar.

Prosesi berikutnya adalah pesamada' yaitu prosesi pemberitahuan kepada si gadis dengan siapa ia akan dikawinkan. Pemberitahuan ini umumnya dilakukan oleh perempuan yang dianggap sepuh dalam keluarga tersebut. Bisanya si perempuan calon pengantin akan menangis mengenang masa muda yang akan segera berakhir. Pada prosesi ini para gadis dari tetangga dan kerabat akan datang untuk memukul rantok (lumping kayu untuk menumbuk padi). Akan terdengar riuh dan sorak sorai yang menjadi pertanda pada khalayak bahwa si calon pengantin telah mengetahui dirinya akan dikawinkan dengan seorang laki-laki.

Prosesi berikutnya adalah Nyorong yaitu proses dimana keluarga laki-laki menghantarkan segala kebutuhan untuk perkawinan yang telah disepakati bersama pada prosesi Basaputis. Pada peristiwa inilah akan terlihat penggunaan pantun Sumbawa atau yang disebut lawas digunakan oleh keluarga kedua belah pihak untuk saling berbalasan. Lawas yang dimaksudkan adalah sebagai berikut:

Pihak laki-laki:

\begin{tabular}{|l|l|}
\hline \multicolumn{1}{|c|}{ Bahasa Sumbawa } & \multicolumn{1}{|c|}{ Bahasa Indonesia } \\
\hline atamu kusorong bangka & Datang diibaratkan perahu besar \\
Balabu ling sinding sia & Mampir didesrmaga \\
Bongkar kebawa kemas gamana & Ambil muatan dengan senyum \\
\hline
\end{tabular}

Jawaban pihak perempuan:

\begin{tabular}{|l|l|}
\hline \multicolumn{1}{|c|}{ Bahasa Sumbawa } & \multicolumn{1}{c|}{ Bahasa Indonesia } \\
\hline Kadatang sangka kuangkang & Anda datang dari depan \\
Muleku santurit kemang & Pulang dengan membawa \\
Lema mampis bawa rungan & kenangan yang baik \\
& Untuk diinformasikan ke \\
& masyarakat banyak \\
\hline
\end{tabular}

Ekspresi verbal dalam perkawinan adat Suku Samawa sudah mulai terlihat dari awal proses perkawinan. Pada saat proses bajajak terjadi dialog dari wakil keluarga pria dengan wakil keluarga wanita, seperti berikut. "nan si hajat kamita bua kami datang perisia lakota, sate tu sambung silaturrahmi anak kami....... ke anak sia ........." (Maksud kedatangan kami untuk bertemu dengan anda, kami mau menyambung silaturrahmi antara anak kami ....... dengan anak anda .........) 
Bahasa daerah yang dipergunakan dalam melakukan proses upacara perkawinan adat adalah bahasa Samawa. Kata-kata yang dipergunakan dalam proses bakatoan sama dengan yang dipergunakan dalam komunikasi sehari-hari masyarakat Suku Samawa. Meskipun demikian, dalam prosesi yang terdapat ekspresi verbal yang berbentuk lawas. Lawas dipergunakan saat proses adat basaputis, strukturnya bahasanya tetap yaitu terdiri dari tiga baris. Bahasa yang dipergunakan berbentuk ungkapan yang mengandung makna konotasi.

\subsection{Makna Simbol}

\subsubsection{Makna Simbol dalam Perkawinan Adat Suku Sasak}

Sebagai puncak acara perkawinan masyarakat Sasak adalah proses Sorong Serah, yang pelaksanaannya memiliki cara tersendiri sebelum pesta perkawinan dilangsungkan. Sorong serah memiliki perlengkapan dan tata cara khusus dengan pemangku adat sebagai pembawa acara. Alat dan bahan yang harus disiapkan oleh keluarga pengantin laki-laki adalah sebagai berikut:

- Olen: seperangkat kain tenun sebagai lambang bahwa pengantin laki-laki telah siap untuk memberikan kebutuhan sandang bagi istrinya.

- Nampak lemah: seperangkat perlatan yang melambangkan bahwa kesiapan pengantin laki-laki dalam memberikan kebutuhan akan pangan atau makanan.

- Pemuput/pemegat: sejumlah uang untuk para saksi adat.

- Sesirah: biasa juga disebut otak bebeli, biasanya berupa kain putih dan hitam yang diikat dengan benang kasur, bermakna sebagi ikatan yang tidak terpisahkan.

- Salin dedeng: sejumlah peralatan dapur, ditambah dengan kain dan mukena sebagai lambang pengganti kasih sayang ibu atau air susu ibu.

- Sedah lanjaran: yaitu berupa seperangkat buah pinang dan rokok khas suku Sasak dari tembakau yang digulung dengan kulit jagung.

Alat yang merupakan seperangkat perlengkapan merupakan perlambang bahwa pengantin laki-laki telah betul-betul bertanggungjawab atas perkawinannya. Proses sorong serah sendiri memiliki serangkaian tata cara sendiri yang dalam hal ini tidak akan dibahas secara khusus. Bila proses sorong serah sudah dilaksanakan maka akan dilanjutkan dengan resepsi atau nyongkolan atau nyombe, yaitu proses arak-arakan pengantin dengan iringan musik tradisional dan masyarakat yang berpakaian adat.

\subsubsection{Simbol dalam Perkawinan Adat Suku Samawa}

Perkawinana adat Suku Samawa memiliki rentetan acara, seperti yang dijelaskan di atas, dalam pelaksanaannya banyak menggunakan peralatan baik berupa benda hidup atau benda tak hidup. Berdasarkan pada kegunaannya masing-masing benda sebagai simbol yang berbeda-beda. Misalnya, tebu, pisang, dan kelapa . pohon tebu yang disebut dalam bahasa Sumbawa baso tebu dipergunakan tiga batang, merupakan sebuah perwujudan agar kedua penganting selalu bertutur kata manis dan lemah lembut. Pisang atau disebut punti saba diambil yang jumlah bijinya 17 dalam satu tandan, merupakan 
simbol dari jumlah rakaat dalam sholat lima waktu. Dengan demikian dihajatkan kedua pengantin tidak pernah lupa untuk melakukan kewajiban sholat lima kali sehari semalam. Disamping itu, ada juga daun sirih, yang dipergunakan adalah daun sirih yang memiliki sirif sejajar bertemu pada satu titik, hla ini simbol dari keutuhan sebuah rumah tangga.

Nilai Perkawinan adat Suku Sasak di Pulau Lombok dan Suku Samawa di Pulau Sumbawa berdasarkan data disajikan seperti berikut ini.

\begin{tabular}{|c|c|}
\hline Perkawinan Adat Suku Sasak & Perkawinan Adat Suku Samawa \\
\hline $\begin{array}{l}\text { 1. Mengandung makna rasa syukur } \\
\text { terhadap sang Khaliq atas segala } \\
\text { kenikmatan yang dilimpahkan. }\end{array}$ & $\begin{array}{l}\text { 1. Mengandung makna rasa syukur } \\
\text { terhadap sang Khaliq atas segala } \\
\text { kenikmatan yang dilimpahkan. }\end{array}$ \\
\hline 2. Memperluas tali silaturrahim & 2. Memperluas tali silaturrahim \\
\hline $\begin{array}{l}\text { 3. Mengembangkan rasa cinta terhadap } \\
\text { budaya sendiri. }\end{array}$ & $\begin{array}{l}\text { 3. Mengembangkan rasa cinta terhadap } \\
\text { budaya sendiri. }\end{array}$ \\
\hline 4. Memupuk hidup bergotong royong. & 4. Memupuk hidup bergotong royong. \\
\hline $\begin{array}{l}\text { 5. Mendidik rasa tanggungjawab } \\
\text { terhadap sebuah ikatan perkawinan. }\end{array}$ & $\begin{array}{l}\text { 5. Mendidik rasa tanggungjawab } \\
\text { terhadap sebuah ikatan perkawinan. }\end{array}$ \\
\hline
\end{tabular}

Sudut pandang terhadap nilai yang terkandung dalam perkawinan adat Suku Sasak di Pulau Lombok dan perkawinan adat Suku Samawa di Pulau Sumbawa, sebagai berikut:

1) Mengandung makna rasa syukur terhadap sang Khaliq atas segala kenikmatan yang dilimpahkan.

2) Memperluas tali silaturrahmi.

3) Mengembangkan rasa cinta terhadap budaya sendiri.

4) Memupuk hidup bergotong royong.

5) Mendidik rasa tanggungjawab terhadap sebuah ikatan perkawinan.

\subsection{Perbedaan Nilai dan Simbol dalam Perkawinan Adat Suku Saasak dan Suku Samawa}

Perbandingan ekspresi verbal dalam perkawinan adat Suku Sasak di Pulau Lombok dan Suku Samawa di Pulau Sumbawa secara garis besar terlihat dari unsur kebahasaan. Berikut perbandingan ekspresi verbal yang ditemukan dalam perkawinan adat Suku Sasak dan perkawinan adat Suku Samawa. 
LINGUA, Vol. 15, No. 2, September 2018

p ISSN: 1979 9411; e ISSN: 2442 238X

Http://lingua.pusatbahasa.or.id; Email:presslingua@gmail.com

Center of Language and Culture Studies, Surakarta, Indonesia

Rosana, Nana; Mahyuni \& Burhanuddin. 2018. Estetika Resepsi Bahasa Sasak para Pembayun

dalam Upacara Adat Sorong Serah Masyarakat Sasak di pulau Lombok.

Lingua (2018), 15(2):187 206. DOI:10.30957/lingua.v15i2.526.

\begin{tabular}{|c|c|}
\hline $\begin{array}{l}\text { Ekspresi verbal perkawinan adat Suku } \\
\text { sasak }\end{array}$ & $\begin{array}{l}\text { Ekspresi verbal perkawinan adat Suku } \\
\text { sasak }\end{array}$ \\
\hline $\begin{array}{l}\text { Saka tahing pamuji mantuk maring Allah } \\
\text { kang hamur ben jagat kang honang gine } \\
\text { sinembah lampinuji ora lian among Allah } \\
\text { sa tunggal. }\end{array}$ & $\begin{array}{l}\text { Batamu kusorong bangka } \\
\text { Balabu ling sinding sia } \\
\text { Bongkar kebawa kemas gamana }\end{array}$ \\
\hline $\begin{array}{l}\text { Ring dine langsonten puniki, deweg } \\
\text { titiang pulih panggih jarwe lan jinarwe. } \\
\text { Moga mogi pepanggihan puniki dados } \\
\text { purun akrab hanjelis tias kelawan ragan } \\
\text { dane sami. }\end{array}$ & $\begin{array}{l}\text { Datang diibaratkan perahu besar } \\
\text { Mampir didermaga } \\
\text { Ambil muatan dengan senyum }\end{array}$ \\
\hline $\begin{array}{l}\text { Sadurung deweg titiang jembaring atur } \\
\text { maring dane-dane sami, mapan deweg } \\
\text { titiang jalmi mukminin kimut maring } \\
\text { syare'at Nabi Muhammad SAW, boten lali } \\
\text { deweg titiang ngasung salam ugami. }\end{array}$ & \\
\hline $\begin{array}{l}\text { Assalamualaikum } \quad \text { Warohmatullahi } \\
\text { Wabarokatuh }\end{array}$ & \\
\hline Pembayun dari pihak pengantin pria & \\
\hline Bismillahirahmanirrohim & \\
\hline $\begin{array}{l}\text { Saya mengajak untuk memanjatkan rasa } \\
\text { syukur kehadirat Allah SWT, zat yang } \\
\text { Maha Tunggal, yang menciptakan langit } \\
\text { dan bumi beserta seluruh isinya. }\end{array}$ & \\
\hline $\begin{array}{l}\text { Salawat dan salam kita panjatkan kepada } \\
\text { junjugan alam Nabi Muhammad SAW, } \\
\text { saya menyampaikan salam agama dengan } \\
\text { ucapan }\end{array}$ & \\
\hline $\begin{array}{l}\text { Assalamualaikum } \quad \text { Warahmatullahi } \\
\text { Wabarakatuh }\end{array}$ & \\
\hline
\end{tabular}

Ekspresi verbal dalam perkawinan adat Suku Sasak, menggunakan bahasa Sasak utami dengan menggunakan kata-kata seperti dalam dialog. Beberapa kata diucapkan keras, sebagian kata diucapkan lirih sesuai makna. Ekspresi verbal dalam perkawinan adat Suku Samawa cenderung beraturan karena menggunakan lawas, yang jumlah baris dalam dialog hanya tiga. Makna yang diucapan merupakan kiasan, dengan sajak yang sama.

\section{SIMPULAN}

Berdasarkan penganalisisan data tentang perkawinan adat Suku Sasak di Pulau Lombok dan perkawinan adat Suku Samawa di Pulau Suwbawa, disimpulkan: 
LINGUA, Vol. 15, No. 2, September 2018

p ISSN: 1979 9411; e ISSN: 2442 238X

Http://lingua.pusatbahasa.or.id; Email:presslingua@gmail.com

Center of Language and Culture Studies, Surakarta, Indonesia

Rosana, Nana; Mahyuni \& Burhanuddin. 2018. Estetika Resepsi Bahasa Sasak para Pembayun

dalam Upacara Adat Sorong Serah Masyarakat Sasak di pulau Lombok.

Lingua (2018), 15(2):187 206. DOI:10.30957/lingua.v15i2.526.

\section{1) Bentuk ekspresi verbal dalam perkawinan adat Suku Sasak dan Suku Samawa}

Ekaspresi verbal yang tampak pada perkawinan adat Suku Sasak di Pulau Lombok ketika dilakukan acara sorong serah aji krama saat pengantin akan menyelesaiakan prosesi adat. Bahasa yang dipergunakan oleh majelis adat yang menunjuk pengemban adat adalah bahasa Sasak utami. Pemangku adat dalam perkawinan Suku Sasak mewakili kedua keluarga pengantin. Bentuk ekspresi verbal yang muncul adalah dialog antara pisolo penyerah dan pisolo penerima (tampi) dan adanya tembang oleh pembayun yang dikumandangkan sesuai kondisi. Ekspresi verbal dalam perkawinan adat Suku Samawa di Pulau Sumbawa, bentuknya berupa lawas yang terdiri dari 3 baris dan bersajak sama. Lawas yang dipergunakan sebagai dialog antara pemangku adat, menggunakan bahasa kias.

\section{2) Makna yang terkandung dalam perkawinan adat Suku Sasak dan Suku Samawa}

Simbol sebgai bentuk analisis semiotik dalam perkawinan adat Suku Sasak di Pulau Lombok dan perkawinan adat Suku Samawa di Pulau Sumbawa, terdapat pada benda atau peralatan upacara yang dipergunakan kedua suku.

Pada perkawinan adat Suku Sasak benda yang menjadi simbol, antara lain kain tenun merupakan simbol tanggungjwab pengantin pria untuk memberikan kebutuhan sandang kepad istrinya. Kain putih dan hitam yang terikat benang kasur, adalah simbol keutuhan. Peralatan rumah tangga, simbol tanggungjawab suami akan kebutuhan pangan sang istri.

Simbol yang dipergunakan dalam perkawinan adat Suku Samawa berupa pohon tebu, pisang, kelapa, dan daun sirih. Pohon tebu adalah simbol untuk selalu berkata halus dan jujur. Pisang, yang dipilih bijinya 17 adalah simbol ketaatan beribadah. Kelapa, adalah simbol untuk dapat beradaptasi seperti pohon kelapa yang bisa tumbuh di mana saja. Daun sirih, yang dipilih siripnya sejajar dan bertemu pada satu titik adalah simbol keutuhan rumah tangga denga satu tujuan yaitu bahagia dunia akhirat.

\section{3) Makna Nilai dan Simbol perkawinan adat Suku Sasak dan Suku Samawa}

Nilai yang terkandung dalam perkawinan adat Suku Sasak di Pulau Lombok dan perkawinan adat Suku Samawa di Pulau Sumbawa, sebagai berikut, 1) Mengandung makna rasa syukur terhadap sang Khaliq atas segala kenikmatan yang dilimpahkan. 2) Memperluas tali silaturrahmi. 3) Mengembangkan rasa cinta terhadap budaya sendiri. 4) Memupuk hidup bergotong royong. 5) Mendidik rasa tanggungjawab terhadap sebuah ikatan perkawinan.

Fungsi perkawinan adat Suku Sasak di Pulau Lombok dan perkawinan adat Suku Samawa di Pulau Sumbawa, sebagai berikut. Sebagai lambang tradisi daerah. 1) Sebagai bentuk pelaksanaan adat istiadat dalam pergaulan sebagai makhluk sosial. 2) Sebagai bagian dari sebuah ritual agama setelah melakukan akad nikah. 3) Sebagai sarana hiburan. 4) Sebagai sarana pemersatu dalam masyarakat. 5) Sebagai bagian dari bentuk pelestarian budaya dan karya sastra 
LINGUA, Vol. 15, No. 2, September 2018

p ISSN: 1979 9411; e ISSN: 2442 238X

Http://lingua.pusatbahasa.or.id; Email: presslingua@gmail.com

Center of Language and Culture Studies, Surakarta, Indonesia

Rosana, Nana; Mahyuni \& Burhanuddin. 2018. Estetika Resepsi Bahasa Sasak para Pembayun

dalam Upacara Adat Sorong Serah Masyarakat Sasak di pulau Lombok.

Lingua (2018), 15(2):187 206. DOI:10.30957/lingua.v15i2.526.

\section{4) Persamaan dan Perbedaan ekspresi verbal}

Perbandingan ekspresi verbal antara perkawinan adat Suku sasak di Pulau Lombok dan perkawinan adat Suku Samawa di Pulau Sumbawa, terlihat adanya persamaan dan perbedaan. Persamaannya adalah bahwa kedua suku dalam perkawinan adat menggunakan bahasa daerah tingkat utami. Perbedaannya, dalam perkawinan adat Suku Sasak, ekspresi verbal diwujudkan dalam bentuk tembang oleh pembayun atau pemangku adat, sedangkan ekspresi verbal dalam perkawinan adat Suku Samawa bentuknya lawas dengan jumlah baris hanya 3 dan bersajak sama.

\section{DAFTAR PUSTAKA}

Arikunto, Suharsimi. 2006. Prosedur Penelitian Sutu Pendekatan. Jakarta: Bina Aksara. Dananjaja, James. 2002. Folklor Indonesia (Ilmu Gosip, Dongeng dan lain-lain). Pustaka Utama Grafiti. Jakarta.

Depdikbud NTB. 1997. Adat Istiadat Daerah NTB. Jakarta: Eka Darma.

Gennette, Gerard. 1980. Narative Discourse. Diterjemahkan oleh Fane E. Lewin dari Discourse du recite oxford. Brasil: Black Weel Ltd.

Mahsun, 2011. Metode Penelitian Bahasa (edisi revisi). Jakarta:Raja Grafindo Persada

Moleong, Lexy J. 2002. Metodologi Penelitian Kualitatif. Bandung: Remaja Rosdakarya.

Pradopo, Rahmat Djoko. 2007 Pengkajian Puisi (Analisis Struktural dan Semiotik). Yogyakarta: Fakultas Sastra UGM.

Rahadi, Kunjana. 2001. Sosiolinguistik, Kode dan Alih Kode. Jogjakarta:Pustaka Pelajar.

Verhaar. 2010. Asas-Asas Linguistik Umum. Jogjakarta:Gadjah Mada University Press. 